\title{
Self-esteem and achievement motivation level in overweight and obese adolescents
}

\section{BACKGROUND}

The increase in the prevalence of obesity and overweight is a global trend, whereas the number of studies devoted to the psycho-social functioning of the overweight young is comparatively small. The objective of this study was to investigate the correlations between the occurrence of overweight and obesity during adolescence and achievement motivation and self-esteem levels, taking into consideration the sex and age of subjects.

\section{PARTICIPANTS AND PROCEDURE}

Altogether, 72 subjects were included in the study. Of them, 36 were overweight $(n=16$; $\mathrm{BMI}=25-29.9)$ or obese $(n=20$; $\mathrm{BMI} \geq 30)$, whereas the control group $(n=36)$ comprised individuals with standard body weight. Both the overweight/ obese group and the control group were composed of $18 \mathrm{fe}-$ males and 18 males. The age range of subjects was 14-21 $(M=17.32 ; S D=2.61)$. The $M$. Rosenberg Self-Esteem Scale, the Questionnaire of Measuring Achievement Motivation (by M. Widerszal-Bazyl), and also a socio-demographic survey, were applied.

\section{RESULTS}

Overweight and obese individuals are characterized by lower (average or low) self-esteem and achievement motivation (they are characterized by a lower perseverance level while performing tasks, perceive time in a less dynamic way, are less future-oriented, and their self-confidence level is lower) than individuals with standard body weight, and who are characterized by high self-esteem and average achievement motivation. In the scope of school mark average, and also of planning higher academic education, there are no intergroup differences. Sex, and also age, does not differentiate overweight or obese individuals in the scope of self-esteem or achievement motivation. Differences occur in the case of comparing individuals of the same sex. Overweight or obese women are characterized by a lower self-esteem level than those whose body mass index is normal. Overweight or obese men are characterized by a lower self-esteem and achievement motivation levels (apart from the above-mentioned indicators, they are characterized by a lower level of ability to delay gratification, and of striving for social recognition) than these whose body mass index is normal.

\section{CONCLUSIONS}

Higher self-esteem occurs together with a stronger motivation achievement in the entire studied group. This correlation does not occur when the group of overweight and obese individuals, and also the control group, are considered separately. In the entire studied group, as well as in subgroups (of overweight and obese, and also of people with normal weight), there is no connection between self-esteem, mean school grades and planning higher academic education.

\section{KEY WORDS}

overweight; obesity; adolescence; self-esteem; achievement motivation

ORganizations - 1: Institute of Psychology, University of Gdansk, Gdansk, Poland, -2: Sonoma County Office of Education, Santa Rosa, USA

AUthors' CONTRIBUtion - A: Study design - B: Data collection - C: Statistical analysis - D: Data interpretation .

E: Manuscript preparation - F: Literature search · G: Funds collection

CORRESPONDInG AUthor - Prof. Wioletta Radziwiłłowicz, Institute of Psychology, University of Gdansk,

4 Bażyńskiego St., 80-952 Gdansk, Poland, e-mail: wioletta.radziwillowicz@ug.edu.pl

to Cite this ARTICLE - Radziwiłłowicz, W., \& Macias, M. (2014). Self-esteem and achievement motivation level in overweight and obese adolescents. Health Psychology Report, 2 (2), 132-143. DOI: 10.5114/hpr.2014.43920 


\section{BACKGROUND}

Obesity and overweight are nowadays one of the fundamental health problems, and the fact that they are commonplace is closely connected with technological progress, whereas increase in the frequency of the occurrence of obesity and overweight among children is a global trend, which has been continuing for the last 35 years at least (Henderson \& Brownell, 2004; Yeung \& Hills, 2008). The scale of the problem of obesity among children and the young is disturbing. Depending on the country, obese children constitute between 3 and $12 \%$ of the population (Ogińska-Bulik, 2004). In accordance with the most recent data, overweight occurs in $8.5 \%$ of children aged 13-15 in Poland, whereas $4.5 \%$ of children in this age group are obese (Wojtyniak, Goryński \& Moskalewicz, 2012; WHO, 2012).

Obesity is s state caused by various factors, both biological and environmental ones. Researchers studying obesity try to explain in detail which genetic and environmental factors are responsible for the onset of obesity. The cases of obesity caused solely by rare genetic mutations are very few, and difficult to consider successfully. When obesity is genetically caused, factors in the environment cause the weight gain process until the moment at which the body reaches the 'programmed' mass (Cope, Fernandez \& Allison, 2004). Determining a genetic factor in the early aetiology of obesity in the case of children will be of significance for preventing obesity among adults. However, diagnostics should develop in the direction of investigating genetic disorders only when child obesity occurs together with delay of maturity, growth or mental retardation (Tounian, 2006).

The cause of excessive food consumption is frequently disorders connected with the regulation of appetite, in particular, incorrect functioning of the satiety mechanism. The functioning of hunger and satiety centres may be influenced by medications, neurotransmitters and hormones (male sexual hormones, and also hormones of the suprarenal glands, increase appetite, whereas the female sexual hormones reduce it) (Ogińska-Bulik, 2004). A diet with high contents of sugars and fats influences the brain tissue, and causes a decrease in the number of neurotransmitters which control good mood, and also results in increased levels of hormones, which are conducive to excessive food consumption.

Apart from biological factors, there are also other causes of overweight and of obesity. There is no consensus among scientists concerning their influence. However, many researchers emphasize the significance of social-cultural factors, as well as psychological ones (Ogińska-Bulik, 2004). Obesity is frequently associated with socio-economic and demographic factors. There is also more and more evidence to sup- port the claim that it is not only genetic factors, but also psychosocial ones, as well as the influence of family (for example, inappropriate eating habits established within it and inherited by children from their parents; providing food, sweets in particular, as a method for complementing insufficient parental feelings; a high level of conflict, and also a lack of cohesiveness in the family system; a high level of maternal control; new and negative events in one's life) that contribute to the occurrence of obesity among adolescents (Ogińska-Bulik, 2004; Łuszczyńska, 2007; Zeller \& Modi, 2008).

Obesity at young age is associated with a risk of the occurrence of many health problems. Among the most frequent obesity complications in the case of children, there are glucose metabolism disorders, endocrinological, respiratory, orthopaedic and skin problems, and also hepatic steatosis and intracranial hypertension (Tounian, 2006). These children are also characterized by a higher number of absences at school due to health problems (Yeung \& Hills, 2008). Moreover, obesity in the period of adolescence is a significant risk factor of the persistent occurrence of this problem in adulthood (Whitaker, Wright, Pepe, Seidel \& Dietz, 1997; Ogińska-Bulik, 2004; Vivier \& Tompkins, 2008).

Apart from consequences for health, obesity at young age is also connected with social isolation, as well as psychological problems. Both relationships with peers and outside appearance are very important for development in the period of adolescence. For that very reason, in this age group psychological results connected with excessive body mass are particularly acute. Obese children and the young, in comparison with their peers with standard body weight, more frequently complain of unpleasant comments connected with their outside appearance. Therefore, the obese young not only struggle with the awareness of not meeting the standards of beauty, but also frequently fall victim to bullying from those peers who may exert an influence on their self-esteem level (Zeller \& Modi, 2008). In developed countries, body image is one of the chief components of the self-esteem of teenagers (particularly of girls) (Levine $\&$ Smolak, 2002). The specific character of the initial phase of the period of adolescence consists, among other things, in a decrease in self-esteem level, and also in paying a lot of attention to outside appearance, in connection with which it may be presumed that in the case of the obese young these phenomena will be even more intensified.

In the period of adolescence, the connections between body image, self-esteem and negative affect are significantly stronger in the case of girls than in the case of boys (Lipowska \& Lipowski, 2006). Already confirmed stronger depressive tendencies of girls at the age of about 14 are connected with negative emotions, associated with changes to their body
Self-esteem and achievement motivation level in overweight and obese adolescents 
and reduced self-confidence. In developed countries, the negative view of the body image contributes to the occurrence of eating disorders, and also of obesity, among young persons and adults (Levine \& Smolak, 2002).

A low quality of peer relationships in childhood results in a greater risk of being rejected by peers, and also of low self-esteem, in the period of adolescence (cf. the review of research in: Zeller \& Modi, 2008). The negative results become transparent even in adulthood, and are relevant to, among other things, a lower level of professional performance, or social relationships. Common opinions concerning the problems in the scope of social relationships in children and the overweight and obese young are confirmed by research (Zeller \& Modi, 2008). In the case of adult women whose obesity developed in childhood, the frequency of falling victim to mischievous jokes in the past is connected with the current dissatisfaction with their body, and also with their self-esteem (Hill \& Lissau, 2002).

The behaviour of peers towards teenagers with excessive body mass also influences the results of slimming therapies. The loss of weight turned out to be positively connected with psychological functioning, and also with better social functioning. The research additionally showed that the results of obesity treatment are better when social support from peers occurs together with therapy in the case of both young persons and adults (Zeller \& Modi, 2008).

Self-esteem may be defined as an attitude to self, either positive or negative. A high self-esteem level is accompanied by the conviction that one is 'sufficiently good'. However, that does not have to mean that an individual with a high self-esteem level considers other people to be inferior. A low self-esteem level, in turn, is sui generis rejection of one's self, which is accompanied by dissatisfaction with oneself. Therefore, self-esteem is synonymous with a conscious, global attitude towards the self, and also emotions revealed towards the self, and connected with cognitive judgements about oneself (Rosenberg, 1965, quoting: Dzwonkowska, Lachowicz-Tabaczek \& Łaguna, 2008; Szostak, 2000).

Self-esteem may be defined as a trait, or, alternatively, as a state. As a trait, it is partly genetically determined, and relatively stable, throughout one's life. However, research shows that self-esteem changes throughout one's life. In its case, both short-, and also long-term, changes occur, and either of them may be gradual or sudden. Self-esteem rises in the period of late childhood, and, subsequently, in the period of late adolescence, and also in that of early adulthood, when the activity is more and more subjected to plans concerning the future (Obuchowska, 2000; Dzwonkowska et al., 2008), whereas it becomes significantly lower at the threshold of adolescence (Mroczkowska, Ziółkowska \& Cwojdzińska, 2007).
Self-esteem as a state is a reflection of the current level of experienced social approval. Defined in this way, it is susceptible to feedback, a level of social approval, and also to the character of impression management.

A low self-esteem level in the case of obese teenagers may result both from the feeling that they do not fulfil certain standards of outside appearance, and also from setbacks suffered in struggling with one's own excessive weight. The identity of obese teenagers is composed, among others, of negative judgements about themselves. They stand out due to their excessive corpulence, experiencing because of it the feeling of being unattractive, which, in turn, is connected with estrangement and low self-esteem (Tabak, 2007).

In accordance with the opinions of many authors, self-esteem influences the aspiration level (Reykowski, 1964; Niebrzydowski, 1973; Szostak, 2000). In the period of adolescence, numerous aspirations are formed, and their contents and strength determine to a large degree the course of further development, and the adopted path of education or career. Aspirations may be determined as desires, wishes or intentions, concerning the results of one's own activities, or achieving a particular state which is a satisfying reward for a given person (Skorny, 1980). Therefore, aspirations stimulate the activity of an individual in a determined direction. A high self-esteem level is usually accompanied by a high aspiration level, whereas a low one is usually accompanied by a low aspiration level.

The formation of aspirations is influenced, among other things, by motivational processes (Skorny, 1980). A motive may be defined as a constant predisposal to move in the direction of certain kind of satisfaction in the case of meeting certain needs. In turn, an achievement motive is a relatively constant predisposal for achievements and success (Atkinson, 1966, quoting: Kupczyk, 1978). An achievement motive may be interpreted as well as an inclination to compete with the standards of perfection (McClelland 1953, quoting: Widerszal-Bazyl, 1978).

In accordance with the theory of motivation of A. Maslow (1964), it is possible to differentiate basic needs, such as physiological needs, of safety or belonging, and also meta needs, for example, the need of self-actualization. Basic needs are deficit needs, which form a hierarchy, whereas growth needs (meta needs) do not form a hierarchy, and their strength is comparable. However, a condition of the appearance of a meta need is having satisfied basic needs first. An aspiration level, in the light of this theory, is dependent on the motivating influence of certain needs. Therefore, it is possible to arrive at the conclusion that, due to frequent rejection by a peer group, in the case of the obese and overweight young their needs of belonging and recognition may be satisfied insuf- 
ficiently, and the consequence of that may be the insufficient formation of the needs of self-actualization and development of one's own abilities.

There are very few studies concerning the psychosocial functioning of the obese young in Poland, whereas successful attempts to standardize psychological tools used for the measurement of body image have been made (Lipowska \& Lipowski, 2013). The objective of the present research was, therefore, to investigate the correlations between the occurrence of overweight and obesity in the period of adolescence and self-esteem and achievement motivation levels, taking into consideration the sex and age of the subjects. In connection with the research objective formulated in this way, a research question about the possible existence of a difference in the scope of self-esteem and achievement motivation between the group of the studied obese and overweight individuals and the groups of subjects with standard body weight was formulated.

As mentioned, stigmatization connected with obesity exerts a negative influence on self-esteem. The research showed that obese teenagers are characterized by a lower global self-esteem level (Zeller $\&$ Modi, 2008). Obese adults and adolescents differed in the scope of self-esteem level when compared with individuals not afflicted by this problem (Byrne \& La Puma, 2007). Therefore, a research hypothesis assuming that the overweight and obese young are characterized by a lower self-esteem level than those with standard body weight was formulated.

The review of the literature indicates that there is a connection between school difficulties of obese children with their achievement motivation. Obese children do not undertake activity on their own in situations which require solving problems. The lack of achievement motivation is the chief problem of obese children whose attitude to school is negative. It should, however, be mentioned that in the research discussed here no psychological tools were used (with the exception of the Thematic Apperception Test, which was used in some of the studies, and in which achievement motivation was considered generally, without taking into consideration its factors) (Rossel, Steffens \& König, 1986). Therefore, another hypothesis, in accordance with which achievement motivation is lower in the case of the overweight and obese young than in the case of the young with standard body weight, was adopted.

Planning higher academic education, and also the school mark average, might be connected with academic achievement motivation. Due to the lack of relevant research into the obese young, the following research question was formulated: do the overweight and obese young less frequently plan to enter higher academic education establishments, and also obtain lower average school marks than the young with standard body weight?
Previously conducted research showed that a high value of BMI in the case of teenage girls was connected with a lower self-esteem level viewed globally (French, Perry, Leon \& Fulkerson, 1996). Both obese girls and boys alike did actually assess their outside appearance less positively than their peers who are not affected by this problem (Tabak, 2007). Girls and boys with excessive body mass less frequently assessed their looks as correct (in comparison with the young from the control group). In the group of obese individuals, the girls assessed their outside appearance negatively twice as frequently, whereas the boys significantly more frequently were of the opinion that they looked good. Therefore, another research question, taking into consideration the inter-sexual differences among the overweight and obese young, was formulated in the following way: does the sex of the studied obese and overweight individuals, and also those with standard body weight, make their self-esteem and achievement motivation levels different?

Longitudinal studies (Strauss, 2000; Byrne \& La Puma, 2007) showed a lack of differences in the scope of self-esteem between nine- and ten-year old obese children and their peers with standard body weight. However, as soon as at the age of 13-14, both obese girls and boys alike had a significantly lower level of global self-esteem than their peers whose body mass was not excessive. Individuals with high self-esteem more frequently accomplish their objectives connected with striving for achievements (Mądrzycki, 1996; Dzwonkowska et al., 2008). The research into adult individuals did not prove, in turn, significant differences in the scope of self-esteem level between obese individuals and individuals who are not affected by this problem (Byrne \& La Puma, 2007). Therefore, the following research question was formulated: does the age of the studied obese and overweight individuals make self-esteem and achievement motivation levels different? The research hypothesis propounding that the self-esteem and achievement motivation of obese and overweight individuals at the age from 14 to 17 is lower than in the case of obese and overweight individuals at the age from 18 to 21 was also formulated.

The influence of achievements and failures on aspirations is dependent on self-esteem (Skorny, 1980). School mark average, and also planning higher academic education, are connected with the academic aspirations of the young. Teenagers whose self-esteem is low dropped out of school more frequently, and, what is connected with that fact, less frequently managed to be admitted to higher academic education establishments (Trzesniewski et al., 2006, quoting: Dzwonkowska et al., 2008). Therefore, the final research question may be presented: do, in the studied group, correlations exist between the following variables: self-esteem, achievement motivation, school mark average, and planning higher academic education?
Self-esteem and achievement motivation level in overweight and obese adolescents 


\section{PARTICIPANTS AND PROCEDURE}

The research included 72 individuals altogether. Of them, 36 were overweight $(n=16$; BMI $=25-29.9)$ or obese $(n=20$; BMI $\geq 30$ ), whereas the control group ( $n=36)$ consisted of individuals whose body mass index (BMI) was between 18.5 and 24.9. Both the group of overweight and obese individuals and the group of individuals with standard body weight were composed of 18 female and 18 male individuals.

Wioletta Radziwiłłowicz, Magdalena Macias

The subjects were aged from 14 to $21(M=17.32$; $S D=2.61)$. They were attendees of secondary schools $(n=32)$ and middle schools $(n=22)$ of the Tri-city (Gdańsk, Gdynia and Sopot); the group also included students of the first year $(n=18)$ of extramural studies (humanities and social major) at the University of Warmia and Mazury in Olsztyn. The majority of the subjects (48) came from large cities (with populations exceeding 150,000 people), 20 individuals came from towns the population of which did not exceed 50,000 people, and only 4 individuals stated that their place of residence was situated in the countryside.

The duration of the problem of overweight or obesity was $5-8$ years in 15 subjects. In 10 subjects, obesity lasted from 6 months to 4 years, and in 6 subjects overweight existed for 13-17 years, whereas in 5 subjects it lasted for 9-12 years.

The following research tools were used in the study: 1. Self-esteem scale - the Rosenberg Self-Esteem Scale (SES). It was developed in 1965 by Morris Rosenberg of the University of Maryland, and it became the most popular tool of measuring self-esteem, interpreted as conviction concerning one's own value. This scale measures general self-esteem levels, considered to be a relatively constant property (Dzwonkowska et al., 2008).

The sum of points obtained in the inventory is in the range 10-40; the higher the result, the higher is the self-esteem (Dzwonkowska et al., 2008). The results of the present research were set against the tool standards.

2. Questionnaire of Measuring Achievement Motivation (Widerszal-Bazyl, 1978).

One of the chief objectives which were intended to be achieved while developing this inventory was developing a tool for measuring the intensity of achievement motivation in general, regardless of the sphere in which an individual wants to be successful. The following assumption was adopted: certain forms of behaviour connected with achievement motivation are observed regardless of the character of objectives (Widerszal-Bazyl, 1978).

The achievement motivation indicators differentiated in the inventory are as follows: determining an intermediate aspiration level; perseverance in the course of performing tasks; the Zeigarnik effect, which means the accurate memorizing of unfinished sentences (assuming that not finishing a sentence is, for all ends and purposes, identical with failure); a long temporal perspective (interpreted as focusing on the future); ability to delay gratification, which means giving up immediate rewards in order to win more valuable, albeit remote in time, rewards; dynamic way of perceiving time; self-confidence (connected with the perception of success as more likely than reality suggests); the lack of strong conformist tendencies, and also striving to achieve social recognition (Widerszal-Bazyl, 1978).

The above-mentioned indicators made it possible for the authors of the tool to differentiate two chief factors: self-assurance (a factor compatible with the description above), and also avoiding confrontations with other people (a factor antagonistic to the description, for example, the lack of perseverance and future-centred attitude, forgetting about the commenced tasks, etc.).

The statements in the inventory contain 2,3 or 5 answers (one is to be selected), and the subjects may receive $1,2,3,4$ or 5 points for each. The greater the number of points $(\min =20, \max =100)$ obtained by a given person, the stronger achievement motivation is. This tool does not have standards; however, it is possible to assume that results much below the mean number of points (60) prove the domination of failure avoidance motivation and confrontations with other people, whereas results significantly higher than average prove the domination of achievement motivation. 3. The survey developed by the author herself, which contains questions concerning sex, age, body mass and height (in order to calculate BMI), address of residence, location of school, and also school mark average, as well as intending to enter (or not) a higher academic education establishment.

\section{RESULTS}

The first analyses were intended to establish whether there is a difference in the scope of self-esteem and achievement motivation between the groups of studied obese and overweight individuals and the group of subjects with standard body weight. In order to answer the questions above, Student's t-test for independent groups was used (Table 1).

On the basis of the above-presented results, it is possible to arrive at the conclusion that the two studied groups differ in the scope of self-esteem $(p<.001)$. In accordance with the standards, overweight and obese individuals obtain low and average results, whereas individuals with standard body weight obtain elevated results. The studied groups also differ in the scope of achievement motivation $(p<.001)$. The group of overweight and obese individuals is characterized by a stronger failure avoidance motivation than the control group, characterized by 
Table 1

Self-esteem and achievement motivation - descriptive statistics and intergroup differences

\begin{tabular}{|c|c|c|c|c|c|c|}
\hline \multirow[t]{2}{*}{ Variables } & \multicolumn{2}{|c|}{$\begin{array}{c}\text { Group with overweight } \\
\text { and obesity }\end{array}$} & \multicolumn{2}{|c|}{ Control group } & \multirow[t]{2}{*}{$t$} & \multirow[t]{2}{*}{$p$} \\
\hline & $M$ & $S D$ & $M$ & $S D$ & & \\
\hline Self-esteem & 27.39 & 5.09 & 32.44 & 2.93 & -5.16 & .001 \\
\hline Achievement motivation & 57.67 & 8.75 & 64.64 & 6.77 & -3.78 & .001 \\
\hline
\end{tabular}

Table 2

Achievement motivation indicators - descriptive statistics and intergroup differences

\begin{tabular}{lccccccc}
\hline \multirow{2}{*}{$\begin{array}{c}\text { Achievement motivation } \\
\text { indicators }\end{array}$} & \multicolumn{2}{c}{$\begin{array}{c}\text { Group with overweight } \\
\text { and obesity }\end{array}$} & \multicolumn{2}{c}{ Control group } & & & $p$ \\
\cline { 2 - 5 } Aspiration level & $M$ & $S D$ & $M$ & $S D$ & & & \\
Delaying gratification & 5.17 & 2.5 & 5.67 & 2.77 & -0.8 & .740 \\
Perseverance & 8.5 & 3.03 & 9.33 & 3.44 & -1.09 & .620 \\
Conformism & 5.39 & 2.52 & 6.72 & 2.15 & -2.42 & .020 \\
Zeigarnik effect & 4.94 & 1.72 & 5.06 & 2.03 & -0.25 & .580 \\
Striving for recognition & 9.25 & 1.75 & 9.81 & 1.93 & -1.28 & .610 \\
Time perception & 3.31 & 1.12 & 3.64 & 0.72 & -1.5 & .670 \\
Self-confidence & 5.47 & 2.13 & 6.42 & 1.16 & -2.34 & .020 \\
Temporal perspective & 6.25 & 1.57 & 7.03 & 1.5 & -2.15 & .040 \\
\hline
\end{tabular}

Self-esteem and achievement motivation level in overweight and obese adolescents a stronger achievement motivation than failure avoidance motivation. Therefore, in accordance with the adopted research hypotheses, both self-esteem and achievement motivation are significantly lower in the case of the overweight or obese young than in the case of the young with standard body weight.

In order to present the differences in the scope of achievement motivation between the overweight/ obese group and the standard body weight group, Table 2, which shows the separate achievement motivation indicators, was added.

As can be concluded from the table above, significant intergroup differences manifest themselves in the four achievement motivation indicators: perseverance $(p<.020)$, time perception $(p<.020)$, self-confidence $(p<.040)$, and temporal perspective $(p<.010)$. The group of overweight and obese individuals obtained significantly lower results on the above-mentioned scales in comparison with the subjects with standard body weight.

The following stage of analysis was aimed at answering the research question concerning the existence of statistically significant differences between overweight and obese individuals and the control group in the scope of school mark average and planning to undertake higher academic education.
The school mark average (in the entire studied group) was $3.57(S D=0.86)$ in the case of the overweight and obese young, and $3.79(S D=0.50)$ in the case of the young with standard body weight. There are no statistically significant differences $(t=-1.35, p=.83)$ between overweight and obese individuals and the control group in the scope of school mark average. Planning to undertake higher academic education was researched among the attendees of middle schools and secondary schools in both of the groups. 16 students who declared that they wanted to undertake higher academic education were overweight or obese, and so did 16 students with standard body weight. 10 overweight and obese students did not have such plans, and nor did 12 students with standard body weight. Between the two studied groups, there are statistically significant differences $\left(\chi^{2}(1)=0.016, p=.900\right)$ in the scope of planning to undertake higher academic education.

The next statistical analysis concerned answering the following research questions, which means investigating differences within the groups, and between them, in the scope of self-esteem and achievement motivation level (Student's $t$-test for independent groups) (Tables 3-6).

On the basis of the analysis of the above-provided data (Table 3), it is possible to conclude that there 
Table 3

Self-esteem and achievement motivation in the group of overweight and obese individuals - descriptive statistics and intersexual differences

\begin{tabular}{|c|c|c|c|c|c|c|}
\hline \multirow{2}{*}{ Variables } & \multicolumn{2}{|c|}{$\begin{array}{c}\text { Female overweight and } \\
\text { obese individuals }\end{array}$} & \multicolumn{2}{|c|}{$\begin{array}{c}\text { Male overweight and } \\
\text { obese individuals }\end{array}$} & \multirow[t]{2}{*}{$t$} & \multirow[t]{2}{*}{$p$} \\
\hline & $M$ & $S D$ & $M$ & $S D$ & & \\
\hline Self-esteem & 27.67 & 4.72 & 27.11 & 5.57 & 0.32 & .650 \\
\hline Achievement motivation & 58.44 & 8.41 & 56.89 & 9.25 & 0.53 & .610 \\
\hline
\end{tabular}

Wioletta

Radziwiłłowicz,

Magdalena

Macias

\section{Table 4}

Self-esteem and achievement motivation in the group of overweight and obese women and in the group of women with standard body weight - descriptive statistics and intergroup differences

\begin{tabular}{|c|c|c|c|c|c|c|}
\hline \multirow[t]{2}{*}{ Variables } & \multicolumn{2}{|c|}{$\begin{array}{c}\text { Female overweight and } \\
\text { obese individuals }\end{array}$} & \multicolumn{2}{|c|}{$\begin{array}{l}\text { Female individuals with } \\
\text { standard body weight }\end{array}$} & \multirow[t]{2}{*}{$t$} & \multirow{2}{*}{$p$} \\
\hline & M & $S D$ & $M$ & $S D$ & & \\
\hline Self-esteem & 27.67 & 4.72 & 31.78 & 2.92 & -3.14 & .001 \\
\hline Achievement motivation & 58.44 & 8.41 & 60.94 & 4.62 & -1.11 & .640 \\
\hline
\end{tabular}

Table 5

Self-esteem and achievement motivation in the group of overweight and obese men and in the group of men with standard body weight - descriptive statistics and intergroup differences

\begin{tabular}{|c|c|c|c|c|c|c|}
\hline \multirow{2}{*}{ Variables } & \multicolumn{2}{|c|}{$\begin{array}{c}\text { Male overweight and } \\
\text { obese individuals }\end{array}$} & \multicolumn{2}{|c|}{$\begin{array}{l}\text { Male individuals with } \\
\text { standard body weight }\end{array}$} & \multirow[t]{2}{*}{$t$} & \multirow{2}{*}{$p$} \\
\hline & $M$ & $S D$ & $M$ & $S D$ & & \\
\hline Self-esteem & 27.11 & 5.57 & 33.11 & 2.87 & -4.06 & .001 \\
\hline Achievement motivation & 56.68 & 9.25 & 68.33 & 6.66 & -4.26 & .001 \\
\hline
\end{tabular}

Table 6

Achievement motivation indicators in the group of overweight and obese men and in the group of men with standard body weight - descriptive statistics and intergroup differences

\begin{tabular}{|c|c|c|c|c|c|c|}
\hline \multirow{2}{*}{$\begin{array}{l}\text { Achievement motivation } \\
\text { indicators }\end{array}$} & \multicolumn{2}{|c|}{$\begin{array}{c}\text { Male overweight and } \\
\text { obese individuals }\end{array}$} & \multicolumn{2}{|c|}{$\begin{array}{l}\text { Male individuals with } \\
\text { standard body weight }\end{array}$} & \multirow{2}{*}{$t$} & \multirow{2}{*}{$p$} \\
\hline & $M$ & $S D$ & $M$ & $S D$ & & \\
\hline Aspiration level & 5.56 & 2.53 & 6.11 & 2.87 & -0.62 & .590 \\
\hline Delaying gratification & 9.00 & 2.93 & 10.83 & 2.89 & -1.89 & .070 \\
\hline Perseverance & 5.39 & 2.72 & 7.72 & 1.57 & -3.15 & .001 \\
\hline Conformism & 4.83 & 1.82 & 5.33 & 2.14 & -0.75 & .660 \\
\hline Zeigarnik effect & 8.83 & 2.03 & 9.50 & 1.98 & -0.99 & .680 \\
\hline Striving for recognition & 3.11 & 1.18 & 3.72 & 0.83 & -1.79 & .080 \\
\hline Time perception & 5.00 & 1.97 & 6.00 & 1.09 & -1.89 & .070 \\
\hline Self-confidence & 6.11 & 1.81 & 7.67 & 1.37 & -2.90 & .010 \\
\hline Temporal perspective & 9.06 & 3.12 & 11.39 & 2.20 & -2.59 & .010 \\
\hline
\end{tabular}


are no statistically significant differences between female and male individuals with excessive weight in the scope of self-esteem (lowered and average results in the case of both sexes) and achievement motivation (the results are more likely to prove failure avoidance motivation than achievement motivation). Statistical analysis did not show significant differences between the groups of overweight and obese individuals of both sexes in the scope of particular achievement motivation indicators.

On the basis of the analysis of the above-provided data (Table 4), it is possible to conclude that the female overweight and obese young have lower self-esteem levels (lowered and average results) than the female young with standard body weight (average and elevated results) $(p<.001)$. In turn, in the case of female individuals no statistically significant difference was found in either of the groups (in both of the groups, the results prove the lack of the domination of failure avoidance motivation, or, alternatively, achievement motivation) in the achievement motivation level between the studied overweight and obese individuals and the subjects with standard body weight. There are no statistically significant differences between these groups in the scope of particular achievement motivation indicators, either.

The same intergroup analysis was conducted in the group of studied male individuals (Table 5). The studied male overweight and obese individuals (lowered and average results) are characterized, in comparison with the studied male individuals with standard body weight (elevated results), by lower self-esteem $(p<.001)$. Achievement motivation is also significantly lower $(p<.001)$ in the case of overweight and obese males (the results are more likely to prove failure avoidance motivation than achievement motivation) than in the control group of male individuals (quite the opposite - results more likely to prove achievement motivation than failure avoidance motivation).

In order to present differences in the scope of achievement motivation between the group of male obese and overweight individuals and the group of male individuals with standard body weight, Table 6, showing the achievement motivation indicators, was included.
Statistically significant differences between the studied male individuals become noticeable in three indicators: perseverance $(p<.001)$, self-confidence $(p<.010)$, and temporal perspective $(p<.010)$. Moreover, there are differences (at the level of a statistical tendency) in the following indicators: delaying gratification $(p<.070)$, striving for recognition $(p<.080)$, and the time perception $(p<.070)$. In the scope of all six above-mentioned achievement motivation indicators, the male overweight and obese individuals obtained lower results than the studied male individuals with standard body weight.

At the following stage of analysis, an attempt was made to determine whether the age of the studied obese and overweight individuals makes them different in the scope of self-esteem and achievement motivation levels. To answer the above question, Student's $t$-test for independent groups was applied (Table 7).

The table above leads to the conclusion that there are no statistically significant differences between overweight and obese individuals (whose age range is either 14-17, or 18-21) in the scope of self-esteem (in both of these age groups, the results are lowered and average) and achievement motivation (the results are more likely to prove failure avoidance motivation than achievement motivation).

The final part of the analysis aimed to answer the research question about the existence of connections between the following variables: self-esteem, achievement motivation, school mark average, and planning higher academic education. Hence, the analysis of correlation (the Pearson $r$ coefficient) between all the above-mentioned variables was conducted. In the entire studied group, there was only one statistically significant, positive and moderate correlation between self-esteem and achievement motivation $(r=.33, p=.010)$. The statistical analysis did not prove significant correlations between self-esteem and school mark average and planning higher academic education. Moreover, the analysis of correlations between the variables self-esteem, achievement motivation, school mark average, and planning higher academic education in separate groups (of overweight and obese individuals, and also of individuals with standard body weight) did not prove statistically significant inter-correlations between them.

\section{Table 7}

Relation between age, and self-esteem and achievement motivation in a group of overweight and obese individuals

\begin{tabular}{|c|c|c|c|c|c|c|}
\hline \multirow{2}{*}{ Variables } & \multicolumn{2}{|c|}{$\begin{array}{l}\text { Overweight and obese } \\
\text { individuals aged } 14-17\end{array}$} & \multicolumn{2}{|c|}{$\begin{array}{l}\text { Overweight and obese } \\
\text { individuals aged } 18-21\end{array}$} & \multirow[t]{2}{*}{$t$} & \multirow{2}{*}{$p$} \\
\hline & $M$ & $S D$ & $M$ & $S D$ & & \\
\hline Self-esteem & 26.31 & 5.63 & 28.25 & 4.59 & -1.14 & .680 \\
\hline Achievement motivation & 57.94 & 8.27 & 57.45 & 9.33 & 0.16 & .870 \\
\hline
\end{tabular}

Self-esteem and achievement motivation level in overweight and obese adolescents 


\section{DISCUSSION}

The issue of the psychological aspects of overweight and obesity is an interesting problem; and attempting to research it is justified due to the current increase in the frequency of occurrence of these problems, and also their psychosocial consequences. They are particularly dangerous in the case of children and the young, not only due to the specific character of the developing organism, but also because of a danger of Wioletta the persistence of these problems throughout one's Radziwiłłowicz, life. The issues studied in this paper - self-esteem, Magdalena and, in particular, achievement motivation - are variMacias ables the level and formation of which in the case of the young may influence their further life. Objectives and ambitions which appear in the period of adolescence usually influence the further course of life of a young person. The aspirations connected with education, or with plans to enter a higher academic education establishment, are quite likely to protect the young against dropping out of school, or commencing criminal activity. Therefore, apart from the health aspect, researching the correlations between overweight and obesity and self-esteem and achievement motivation in the case of the young is of significance also in the context of searching for the causes of the determinations of the young which influence their further life.

The results of the present research into a group of 72 individuals confirmed the existence of a connection between self-esteem and achievement motivation. However, they did not show the existence of a connection between self-esteem and achievement motivation in the group of overweight and obese individuals, or in the group of individuals with standard body weight, considered separately. Perhaps, what was of importance here was the fact that both of the groups were too small. Our research did not prove, either, the existence of a connection between self-esteem and school mark average, or planning higher academic education. That is not compatible with the results of the research conducted by Dyson (1967; quoting: Kulas, 1986), which proved that students with outstanding learning achievements also had higher self-esteem than those who were less successful in learning. The connection between self-esteem and learning achievements was also proved by other research, conducted on a group of 194 secondary school attendees (Kulas, 1986). The research proved that there exists a significant difference in the scope of learning achievements among the young, depending on the self-esteem level (defined as the correlation between 'the real self' and 'the ideal self'). In the research, the influence of the variable constituted by a general mental level was eliminated. The best academic results were achieved by the subjects with high self-esteem levels. However, few students having low self-esteem functioned very effectively in school. The development of interests or intellectual involvement in a particular field of knowledge constituted a compensation in the case of the subjects having low self-esteem, who did not participate much in social life, or were socially maladjusted. Perhaps the lack of a statistically significant correlation between self-esteem and the school mark average was revealed in our research because of, in the case of some of the subjects having low self-esteem, the effect of compensation of the lack of social skills, and striving for academic achievements connected with that.

One of the objectives of our study was to investigate whether individuals in the period of adolescence have a lower self-esteem and achievement motivation than those with standard body weight. The results of the research confirmed these suppositions. The individuals characterized by an excessive body mass are less satisfied with themselves, and are less convinced that they are 'sufficiently good' than individuals from the group in which body weight was standard. The global attitude towards self in the case of obese and overweight individuals is less positive than in the other group. A lower self-esteem in the case of obese and overweight individuals is not conducive to the formation of convictions which justify undertaking actions on the assumption that a man has an influence on events, and is able to overcome obstacles which are encountered. Convictions of this kind are necessary for drawing up ambitious plans and facing challenges (Mądrzycki, 1996; Bandura, 1997). The results of our research are also compatible with those of several other studies, which proved that self-esteem is significantly lower in the case of children with overweight or obesity than in the case of children with standard body weight (Kimm, 1997; Strauss, 2000; quoting: Field, 2006; Tabak, 2007).

In turn, the results of our research which proved a lower achievement motivation level in the case of the overweight and obese young in comparison with the young with standard body weight are not confirmed by the results of the research of other authors (Rossel et al., 1986). They studied 'hope for success' (understood as a competence, and also belief in success and the possibility of overcoming obstacles on the road to accomplishing ambitious task). In the group including both girls and boys aged 10-13, the hypothesis of a lower level of hope for success in the group of obese individuals was not confirmed. It is possible that differences in the results of research originate from different operationalization of the notion of achievement motivation. This is so because the inventory of M. Widerszal-Bazyl (1978) takes into consideration not only orientation on the future or self-confidence (connected with confidence in one's own abilities), but also variables such as perseverance while completing tasks and the dynamic time perception (feeling that it passes quickly). All four 
above-mentioned achievement motivation indicators were, in our research, at a lower level in the group of the studied obese and overweight individuals in comparison with the subjects with standard body weight.

Another issue raised in the present study was that of academic achievements among obese and overweight individuals. Our research did not prove differences between overweight and obese individuals and those with standard body weight in the scope of school mark average or planning higher academic education (that aspect was studied only in reference to middle school attendees, and also secondary school attendees). Perhaps it is caused by the above-mentioned compensation of social isolation among individuals with excessive weight. If they feel ashamed in situations of social exposure, or prefer the 'sedentary' lifestyle, then, by means of good school performance, they can somehow 'materialize' in the group. If they feel alienated and less frequently spend time with the group of their peers than gaining the recognition of teachers they may in a way 'make up for' the fact that their social functioning is not infrequently not very competent (Zeller \& Modi, 2008). In our research, obese and overweight individuals were considered a single group (due to the difficulties connected with the choice of the appropriate numbers of individuals whose body mass index would be a sign of the occurrence of obesity). Perhaps, that is the reason why the results of our research differ in comparison with the results of the research of those scientists who took into consideration only obese individuals and compared them with individuals with standard body weight.

From the point of view of the objectives of our paper, in connection with self-esteem and also achievement motivation levels among overweight and obese individuals, it was also important to take into consideration intersexual differences. The results of the research indicated that sex does not cause a difference between obese and overweight individuals in the scope of self-esteem, and also of achievement motivation. However, differences appear when individuals of the same sex are compared. In the case of female overweight and obese individuals, the self-esteem level is lower than in the case of female individuals from the control group. Our results confirm the research which indicated that a higher body mass index was connected with lower global self-esteem in the case of girls (Hill \& Lissau, 2002). Our research also proved that female individuals having a different BMI do not differ significantly between each other in the scope of the achievement motivation level. This is compatible with the previously cited result which proved that the difference between obese teenagers and the control group in the scope of 'hopes for success' occurred only in the case of boys (Rossel et al., 1986). It was also found in our research that a correlation between BMI and achievement motivation was visible only in the case of male individuals. Those of them in whose case overweight or obesity was diagnosed were characterized by a lower perseverance level while executing tasks, self-confidence, ability to delay gratification, striving for social recognition, a lower level of future-concentrated attitude, and also perceiving time in a less dynamic way. The lack of differences between overweight and obese girls and girls with standard body weight (in the scope of an achievement motivation level), and also the occurrence of differences of this kind among boys may be interpreted as a result of diversity in the scope of sex roles. Among girls, there is less competition, and they face situations triggering competition and the need to prove their achievements less frequently than boys. In turn, in the case of boys an important factor determining their role in a group is sporting competitions and academic achievements (Rossel et al., 1986). Some researchers associate the occurrence of obesity with the culture of individualism. In the context of the above-described results, what seems to be interesting is the words of a teenage patient of Michael Rich, a Boston M.D., who distributed to his obese patients cameras so as to make it possible for them to record their thoughts. 'I like the way I am! However, on the other hand, if you do want to get slimmer, do it for yourself, and because you want to, and not because society exerts a pressure on you... I could have become slimmer a long time ago already, but it has never happened because I said so (...) to the entire world. I do not have to conform to any ideals! (Okie, 2005, p. 70). There is no doubt that the positive attitude to oneself is demanded from the psychological point of view; however, teenagers nearly deliberately opposing cultural trends and binging are not aware of medical complications connected with obesity, or the risk that they will remain obese throughout their entire lives.

Our research also proved lower self-esteem levels in the case of the male overweight and obese individuals in comparison with the male individuals from the control group. Other research proved as well that the higher BMI in the case of boys was connected with a lower level of their own competence in the fields of physical fitness, outside appearance, and also self-esteem in romantic relationships, although not with global self-esteem (French et al., 1996). The research showed that the global self-esteem level in the case of obese 13-14 year old boys and girls alike was significantly lower than that of their peers who were not affected by obesity (Strauss, 2000; Byrne \& La Puma, 2007). These studies also proved the lack of a difference in self-esteem level between 9-10 year old individuals who are obese and those who are not. In our research also comparisons in the scope of age were taken into consideration. However, individuals (obese and overweight) at the age 14-17, and also 18-21, were compared. Our research did not show
Self-esteem and achievement motivation level in overweight and obese adolescents 
significant differences between these groups in the scope of self-esteem level, or achievement motivation. Taking into consideration self-esteem, the results of our research are partly compatible with the results which show that self-esteem connected with outside appearance is strongly associated with global self-esteem throughout the entire period of adolescence, and also in the later period of life (Harter, 1993; quoting: Hill \& Lissau, 2002). In turn, there is no research devoted to the issue of generally measured achievement motivation in the case of young with excessive weigh dependent on their age.

The issues of self-esteem and achievement motivation in the case of obese individuals are not, therefore, fully studied. The results of the research in the scope of those issues are not free of ambiguity. Researchers frequently adopt various definitions of overweight as well. Sometimes, it is described as $120 \%$ of the perfect weight, and sometimes as BMI over the sixty-seventh quartile (Hill \& Lissau, 2002). Sometimes, weight is also considered as a permanent variable taken into consideration in the analysis of correlations, and also regression (French et al., 1996). Further research into psychological factors contributes to the excessive weight; therefore, they require taking into consideration, e.g. correlations of global self-esteem, and also self-assessment connected with their outside appearance. It would also be interesting to take into consideration various fields in which obese individuals reveal their achievement motivation, issues of the feeling of control and the collapse of self-regulation in individuals striving for ambitious achievements in fields different than outside appearance, and also perfectionism in other spheres of life than way of eating.

\section{CONCLUSIONS}

1. Overweight and obese individuals are characterized by lower self-esteem and achievement motivation levels than individuals with standard body weight. In the scope of school mark average, and planning higher academic education, there were no intergroup differences.

2. Sex and age do not result in differences between individuals with overweight and obesity in the scope of self-esteem or achievement motivation. Differences are observed in the case of comparison between individuals of the same sex. Overweight or obese women are characterized by a lower self-esteem level than those whose body mass index meets standards. Males with overweight or obesity are characterized by lower self-esteem and achievement motivation levels than those whose body mass index meets standards.

3. Higher self-esteem is accompanied by stronger achievement motivation in the entire studied group. This correlation does not occur when the group of studied overweight and obese individuals, and a group of individuals with standard body weight, are considered separately. In the entire studied group, as well as in the subgroups of subjects (of the overweight and obese, and also of those with standard body weight), there is no connection between self-esteem and the school mark average, or planning higher academic education.

\section{REFERENCES}

Bandura, A. (1997). Self-efficacy: The exercise of control. New York: Freeman.

Byrne, S. M., \& La Puma, M. (2007). Psychosocial aspects of childhood obesity. In: A. P. Hills, N. A. King, \& N. M. Byrne (eds.). Children, obesity and exercise. Prevention, treatment and management of childhood obesity (pp. 80-89). Padstow, Cornwall: Routledge, Taylor \& Francis Group.

Cope, M. B., Fernandez, J. R., \& Allison, D. B. (2004). Genetic and biological risk factors. In: J. K. Thompson (ed.). Handbook of eating disorders and obesity (pp. 323-338). Hoboken, NJ: John Wiley \& Sons.

Dzwonkowska, I., Lachowicz-Tabaczek, K., \& Łaguna, M. (2008). Samoocena i jej pomiar. Polska adaptacja skali SES M. Rosenberga [Self-esteem and its measurement. Polish adaptation of the SES - Rosenberg Self-Esteem Scale]. Warszawa: Pracownia Testów Psychologicznych.

Field, A. (2006). Epidemiology of the Health and Economic Consequences of Pediatric Obesity. In: M. Goran, \& M. Sothern (eds.). Handbook of pediatric obesity (pp. 1-18). Boca Raton, FL: Taylor \& Francis Group. French, S. A., Perry, C. L., Leon, G. R., \& Fulkerson J. A. (1996). Self-esteem and change in body mass index over 3 years in a cohort of adolescents. Obesity Research, 4, 27-33.

Henderson, K. E., \& Brownell, K. D. (2004). The toxic environment and obesity: contribution and cure. In: J. K. Thompson (ed.). Handbook of eating disorders and obesity (pp. 339-348). Hoboken, NJ: John Wiley \& Sons.

Hill, A. J., \& Lissau, I. (2002). Psychosocial Factors. In: W. Burniat, T. Cole, I. Lissau \& E. Poskitt (eds.). Child and Adolescent Obesity. Causes and Consequences, Prevention and Management (pp. 109-127). New York: Cambridge University Press.

Kulas, H. (1986). Samoocena mtodzieży [Self-esteem of adolescents]. Warszawa: Wydawnictwa Szkolne i Pedagogiczne.

Kupczyk, J. (1978). Uwarunkowania aspiracji życiowych mtodzieży w starszym wieku szkolnym [Determinants of life aspirations of adolescents in the older school age]. Poznań: Wydawnictwo Naukowe Uniwersytetu im. Adama Mickiewicza w Poznaniu. 
Levine, M. P., \& Smolak, L. (2002). Body Image Development in Adolescence. In: T. F. Cash \& T. Pruzinksy (eds.). Body Image. A Handbook of Theory, Research, and Clinical Practice (pp. 74-82). New York, NY: The Guilford Press.

Lipowska, M., \& Lipowski, M. (2006). Poziom optymizmu a akceptacja własnego ciała przez kobiety w okresie adolescencji [Level of optimism and acceptance of own body by adolescent women]. Psychologia Rozwojowa, 11, 89-96.

Lipowska, M., \& Lipowski, M. (2013). Polish normalization of the Body Esteem Scale. Health Psychology Report, 1, 72-81.

Łuszczyńska, A. (2007). Nadwaga i otyłość. Interwencje psychologiczne [Overweight and obesity. Psychological interventions]. Warszawa: Wydawnictwo Naukowe PWN.

Maslow, A. H. (1964). Teoria hierarchii potrzeb [Need hierarchy theory]. In: J. Reykowski (ed.). Problemy osobowości i motywacji w psychologii amerykańskiej [The problems of personality and motivation in American psychology] (pp. 135-164). Warszawa: Wydawnictwo Naukowe PWN.

Mądrzycki, T. (1996). Osobowość jako system tworzący i realizujacy plany [Personality as a system of creating and implementing plans]. Gdańsk: Gdańskie Wydawnictwo Psychologiczne.

Mroczkowska, D., Ziółkowska, B., \& Cwojdzińska, A. (2007). Zaburzenia odżywiania: poradnik dla rodziców i bliskich [Eating disorders: a guide for parents and relatives]. Warszawa: Wydawnictwo Naukowe Scholar.

Niebrzydowski, L. (1973). Kształtowanie się samooceny w okresie dorastania [Development of self-esteem in adolescence]. Gdańsk: Uniwersytet Gdański.

Obuchowska, I. (2000). Adolescencja [Adolescence]. In: B. Harwas-Napierała \& J. Trempała (eds.) Psychologia rozwoju człowieka [Human Developmental Psychology] (pp. 163-200). Warszawa: Wydawnictwo Naukowe PWN.

Ogińska-Bulik, N. (2004). Psychologia nadmiernego jedzenia. Przyczyny, konsekwencje, sposoby zmian [Psychology of excessive eating. Causes, consequences, ways to change]. Łódź: Wydawnictwo Uniwersytetu Łódzkiego.

Okie, S. (2005). Fed up! Winning the war against childhood obesity. Washington, D.C.: Joseph Henry Press.

Reykowski, J. (1964). Problemy osobowości i motywacji w psychologii amerykańskiej [The problems of personality and motivation in American psychology]. Warszawa: Wydawnictwo Naukowe PWN.

Rossel, E., Steffens, W., \& König, R. (1986). Entwickeln adipöse Kinder eine geringere Leistungsmotivation? Praxis der Kinderpsychologie und Kinderpsychiatrie, 35, 164-169.

Skorny, Z. (1980). Aspiracje mtodzieży oraz kierujace nimi prawidtowości [The aspirations of adolescents and directing them regularity]. Wrocław: Zakład Narodowy im. Ossolińskich - Wydawnictwo.

Strauss, R. S. (2000). Childhood obesity and self-esteem. Pediatrics, 105, e15, http://pediatrics.aappublications.org/content/105/1/e15.full.html

Szostak, J. (2000). Samorealizacja i samoocena mtodzieży [Self-realization and self-esteem of adolescents]. Warszawa: Wydawnictwo Wyższej Szkoły Ekonomiczno-Informatycznej.

Tabak, I. (2007). Zadowolenie z życia i poczucie własnej wartości [Life satisfaction and self-worth]. In: A. Oblacińska \& M. Jodkowska (eds.). Otyłość u polskich nastolatków - epidemiologia - styl życia - samopoczucie. Raport z badań uczniów gimnazjów w Polsce [Obesity in Polish teenagers - epidemiology - lifestyle - being. Research report among junior high school students in Poland] (pp. 10-105). Warszawa: Wydawnictwo Ezdorat.

Tounian, P. (2006). Historia naturalna otyłości u dzieci [The natural history of obesity in children]. In: P. Tounian (ed.). Otytość u dzieci [Obesity in children] (pp. 48-64). Warszawa: Wydawnictwo Lekarskie PZWL.

Vivier, P., \& Tompkins, C. (2008). Health Consequences of Obesity in Children and Adolescents. In: E. Jelalian \& R. G. Steele (eds.). Handbook of Childhood and Adolescent Obesity (pp. 11-24). New York, NY: Springer Science + Business Media

Whitaker, R. C., Wright, J. A., Pepe, M. S., Seidel, K. D., \& Dietz, W. H. (1997). Predicting obesity in young adulthood from childhood and parental obesity. New England Journal of Medicine, 105, 145-150.

Widerszal-Bazyl, M. (1978). Kwestionariusz do mierzenia motywu osiągnięć [Questionnaire of Measuring Achievement Motivation]. Przeglad Psychologiczny, 21, 355-367.

Wojtyniak, B., Goryński, P., Moskalewicz, B. (2012). Sytuacja zdrowotna ludności Polski i jej uwarunkowania [The health situation of the Polish population and its determinants]. Warszawa: Narodowy Instytut Zdrowia Publicznego - Państwowy Zakład Higieny.

World Health Organization (2012). Social inequalities in health in Poland. Denmark: WHO Regional Office for Europe.

Yeung, J., \& Hills, A. P. (2008). Childhood obesity - an introduction. In: A. P. Hills, N. A. King \& N. M. Byrne (eds.). Children, obesity and exercise. Prevention, treatment and management of childhood and adolescent obesity (pp. 1-10). London, UK: Routledge Taylor \& Francis Group.

Zeller, M. H., \& Modi, A. C. (2008). Psychosocial Factors Related to Obesity. In: E. Jelalian \& R. G. Steele (eds.). Handbook of Childhood and Adolescent Obesity (pp. 25-42). New York, NY: Springer Science + Business Media.
Self-esteem and achievement motivation level in overweight and obese adolescents 